\title{
Når det haster
}

\author{
Helsedirektoratet arbeider nå med å utvikle den medisinske nødmeldetjenesten ytterligere. Viktige elementer \\ i dette arbeidet er utarbeiding av en bedre koordinering mot de andre nødetatene, og sikring av et best mulig \\ nødnett.
}

22. juli 2011 viste oss nok en gang hvor viktig det er at hele den akuttmedisinske kjeden fungerer. Derfor deler Helsedirektoratet fagmiljøenes engasjement for at den medisinske nødmeldetjenesten skal utvikles ytterligere gjennom både forskning og fagutvikling. Helsedirektoratet arbeider nå aktivt med å systematisere erfaringene og anbefalingene fra direktoratets egen 22 . julievaluering og 22. juli-kommisjonens rapport slik at disse blir fulgt opp og nødvendige tiltak implementert. Vi har utgitt en statusrapport for medisinsk nødmeldetjeneste, Mot lysere tider der sentrale fagmiljøer og nasjonale kompetansetjenester peker på viktige utfordringer og muligheter for videre utvikling av medisinsk nødmeldetjeneste og den akuttmedisinske kjede (1).

Spørsmålet om hvordan vi kan få en tettere og bedre koordinering mot de andre nødetatene (brann og politi) står sentralt. Vi skal utvikle innholdet i tjenesten samtidig med at vi innfører en ny sambandsløsning. Det gamle Helseradionettet skal ut. Inn kommer det nye, digitale nødnettet for bedre talekommunikasjon.

I samarbeid med Direktoratet for nødkommunikasjon og de andre nødetatene arbeider Helsedirektoratet intensivt for å sikre et best mulig nødnett. Det pågår blant annet flere omfattende prosesser for å sikre at nødnettet får tilstrekkelig dekning både innen- og utendørs og i landets tunneler, tilstrekkelig talekapasitet og sikkerhet mot ytre påvirkninger. Det er behov for å avklare om nettet kan gi tilstrekkelig databæringskapasitet eller om det må suppleres med andre løsninger. Vi må også få en bedre teknisk løsning for samtlige av landets akuttmottak og legevaktsentraler.

\section{Ny teknologi}

Innføring av ny teknologi kan understøtte en optimal organisering av den akuttmedisinske kjede. Det berører blant annet nødnummerproblematikken. I likhet med de fleste andre land i Europa har Norge allerede det felles nødnummeret 112. Samtidig har Helsedirektoratet argumentert for viktigheten av å differensiere nødnumrene gjennom at man, som $i$ en rekke andre europeiske land, beholder et eget nødnummer til helsetjenesten - 113. I likhet med Legeforeningen, Helsetilsynet og akuttmedisinske fagmiljøer er Helsedirektoratet opptatt av å sikre den medisinske fagligheten som nå ligger i «113-systemet». Den sikrer befolkningen direkte kontakt med helsetjenesten når det virkelig haster. Den som ringer 113, kommer alltid direkte til en akuttmedisinsk kommunikasjonssentral (AMK), døgnbemannet med minst to helsepersonell opplært og trent spesielt for denne oppgaven. Det man har av forskning og statistikk tyder på at dette nummeret fungerer godt. Folk kjenner til 113, det har få feiloppringinger, de som ringer er i akutt helsenød og nummeret besvares raskest av samtlige nødnumre. Innføringen av ett felles legevaktnummer (116117) vil forsterke befolkningens direkte tilgang til helsehjelp. Internasjonal forskning tyder på at Norge ligger $i$ front med hensyn til overlevelse og helsetilbud til store pasientgrupper som hver dag får helsehjelp gjennom nødnummer 113. Vi oppnår på flere områder resultater som ligger godt over tilsvarende resultater $i$ andre vestlige land, som f.eks. ved hjertestans og hypotermi $(2,34)$.

\section{Samhandling}

Det neste spørsmålet er hvordan vi best kan forbedre samhandlingen med de andre nødetatene. Her går det flere parallelle spor som skal gi oss en bredere erfarings- og kunnskapsbase. Et av områdene det er spesielt stor politisk og faglig debatt omkring er samlokalisering og samorganisering av nødmeldesentraler. Regjeringen har besluttet at noe av dette skal utprøves gjennom en pilot i Drammen der man allerede har samlokalisert de tre nødetatene brann, politi og helse (SAMLOK-prosjektet). Piloten er under evaluering av Helsedirektoratet i samarbeid med Direktoratet for samfunnssikkerhet og beredskap (DSB) og Politidirektoratet (POD).

En videreføring som skal prøve ut felles samorganisering av nødetatene med bruk av kun ett nødnummer er under planlegging. Også denne delen av piloten vil bli gjenstand for forskning og nødvendig evaluering for å utvikle ny kunnskap.

Nasjonalt kunnskapssenter for helsetjenesten fikk 10.5. 2012 i oppdrag å se på effekter av samlokalisering, samorganisering og felles nødnummer. Den foreløpige rapporten viser et svakt internasjonalt kunnskapsgrunnlag, med bare to nyere rapporter. Disse nyere rapportene peker dog på at felles sentraler i Finland blant annet synes å øke både responstiden og bruken av ambulanse (4).

\section{Flere strategier}

Utover samlokalisering, samorganisering og nødnummer følger Helsedirektoratet flere andre spor som kan utvikle samarbeidet både internt $\mathrm{i}$ helsetjenesten og mellom nødetatene. Åpne «samtalerom» i det nye nødnettet kan sammen med annen kommersielt tilgjengelig teknologi, i praksis gi felles, virtuelle operasjonssentraler.

I tillegg bør man gå videre med teknologiske pilotprosjekter, som eksempelvis VAKe-prosjektet i Helse Nord, Helse Vests satsing på virtuelle AMK-sentraler og bruk av digitale kart, felles ressursvisning og informasjonsdeling. Når man har tilstrekkelig erfaringsgrunnlag, kan denne type løsninger raskt komme på plass nasjonalt.

Det overordnede målet er at Norge fortsatt skal kunne hevde seg godt med henblikk på overlevelse og livskvalitet ved livstruende hendelser og samtidig ha optimal samhandling mellom alle nødetatene når det er behov for det.

Bjørn Guldvog

postmottak@helsedir.no

Bjørn Guldvog (f. 1958) er konstituert direktør i Helsedirektoratet.

Forfatter har fylt ut ICMJE-skjemaet og oppgir ingen interessekonflikter.

\section{Litteratur}

1. Helsedirektoratet. www.helsedirektoratet.no/ publikasjoner/rapport-fra-nasjonalutviklingskonferanse-formedisinsknodmeldetjeneste/Sider/default.aspx (22.11.2012)

2. Lindner TW, Søreide E, Nilsen OB et al. Good outcome in every fourth resuscitation attempt is achievable-an Utstein template report from the Stavanger region. Resuscitation 2011; 82 1508-13.

3. Nilsen JML, BøI, Rasmussen JR. Doubled survival from prehospital cardiac arrest in a rural commu nity in North-Norway following implementation of an aggressive chest pain protocol with early prehospital thrombolysis for STEMI. Abstrakt 2011 SS-A-17087-AHA. Scientific Sessions Nov. 2011 Dallas, TX: American Heart Association, 2011.

4. Nasjonalt kunnskapssenteret for helsetjenesten, Notat 2012 - Hurtigoversikt Effekt av å innføre et felles nasjonalt nødnummer for helsetjeneste, brann og politi. www.kunnskapssenteret.no/ Publikasjoner/Effekt+av+\%C3\%A5+innf\%C3\% B8re+et+felles+nasjonalt+n\%C3\%B8dnummer+ for+helsetjeneste $\% 2 \mathrm{C}+$ brann+og+politi.16161.cms (23.11.2012).

Mottatt 2.11. 2012, første revisjon innsendt 21.11. 2012, godkjent 22.11. 2012. Medisinsk redaktør Anne Kveim Lie.

Publisert først på nett 11.12. 2012. 